\title{
A critical view of educational research in China over 20 years: A content analysis of the journal of Educational Research
}

\section{Wang, Hong}

Faculty of Education, Southwest University, China(57179149@qq.com)

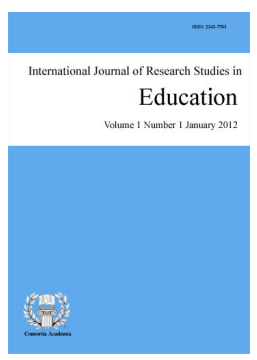

ISSN: 2243-7703 Online ISSN: 2243-7711

Accepted: 13 July 2015

OPEN ACCESS

\section{Abstract}

This study is aimed at exploring trends of educational research in China as reflected in 3922 articles published in the journal of Educational Research (Jiao Yu Yan Jiu) (ER) from 1994-2014. A content analysis was used to discover the features and trends of educational research and to examine the influence and international development of the journal in terms of sub-disciplines, key topics, research methodologies, age-related educational levels, authors' backgrounds and references. The findings identify important research orientations, major research fields, key research concepts, neglected areas in educational research and the relation between educational research and practice and policy-making. The results suggested that indigenization and politicization of educational research was highlighted whilst internationalization was neglected. Discussions and implications of the findings are also considered.

Keywords: educational research; content analysis; educational trend; educational development; journal of Educational Research 


\section{A critical view of educational research in China over 20 years: A content analysis of the journal of Educational Research}

\section{Introduction}

The past 20 years of China is a socially and economically transitional period that consequentially affects educational research in China. Research paradigm and focuses of educational research in the period may be different from that before. Zhang (2010) thought since the founding of People's Republic of China educational research has experienced two times of paradigm transformations: the first transformation is from political educational paradigm to performance-based system paradigm; the second is from performance-based system paradigm to culturology paradigm which started in the beginning of 1990s. How would these changes affect educational research? Some researchers pointed out that educational research in China has made great progress in establishing Chinese characteristic education theories, affecting education policies and practice and connecting to the outside world, especially Europe, North American and Japan (Liu \& Wang, 2013). But others argued that one of the problems of educational research in China is the lack of international perspective - a reflection of refusing education internationalization with excuse for solving uniquely domestic problems (Gan, 2013). And educational research in China remains outside the main current of that in the world and Chinese scholars' voices can hardly be heard in the world's education circle (Pan, 2006). These arguments indicate that educational research in China over the past 20 years was full of changes and controversies.

To explore features and changes of educational research in those years, this study focuses on one single journal, the journal of Educational Research (Jiao Yu Yan Jiu) (ER), as an example of case study. ER is a comprehensive printed periodical that is considered China's top publication on education. Since its inauguration in 1979, ER has been "widely regarded as the most authoritative journal in the field of education in China as it witnesses the history and development of Chinese educational research more completely than other educational journals" (Zhang, Chen, Zhu, \& Luo, 2009). It has thus been in a unique position to "influence educational research in China and represent the highest achievement of it" (Tian \& Shang, 2003). According to a report, ER ranks first among all Chinese educational journals in terms of citation rates and impact factors (Institute of Scientific and Technical Information of China, 2011). Therefore, studying ER provides a distinctive opportunity to examine how education in China has defined itself and what approaches to education have been represented in a journal which advocated a comprehensive, inclusive and pluralist position as it became the top academic journal in China. In addition to that, the study also intends to explore ER's global perspective as it continues to extend its influence worldwide by internationalization.

This study's purpose was to explore education trends in China as reflected in ER from 1994 to 2014. The main research objective was to discover any features and trends in education through a quantitative content analysis of papers published in $E R$ across two decades, noting changes over time and offering a qualitative interpretation.

\subsection{Research questions}

During the initial process of the discussion of this study we considered what data would be available to be mined from published papers and the CNKI (China National Knowledge Infrastructure) database. Based on these data sources we decided that there was a reasonable expectation of being able to address and answer the following research questions: (1) To what extent have sub-disciplines (educational principles, curriculum and teaching, education history, comparative education, special education, educational technology, educational law, educational economy and management, teacher education and educational psychology ) been represented in $E R$ ? (2) To what extent have particular topics been represented in ER? (3) To what extent have different research methods and methodologies been represented in ER? (4) To what extent have different age-related educational 
A view of educational research in China: A content analysis of the journal of Educational Research

levels been represented in $E R$ ? (5) What background information is available about authors whose articles have been published in ER? (6) What background information is available about references of articles published in ER?

\section{Methods}

\subsection{Sample}

$E R$ used to be a bimonthly journal when it started publication in 1979, and it then changed into a monthly publication the next year. This research used content analysis to investigate education trends in China over 20 years as reflected in ER from the first issue published in 1994 to the sixth issue published in 2014. Over the 20 years, 3922 papers have been published. The number of issues and papers published on $E R$ has increased slightly since 1994. The average number of papers published per year is 196 . The maximum number of papers published was in 2012 ( $f=299)$ and the minimum was in $1999(f=146)$.

\subsection{Procedures and measures}

The author led this research and, together with three graduate students whose majors were education. The content analysis methodology involved four main steps. First, we defined the content to be examined and articulated the research questions listed above. In conducting a quantitative analysis of 3922 papers we included forum abstract but excluded news and conference reports, information about academic activities, book review and notes. Second, we developed categories relating to the six research questions, drawing on our study of the field. In the first category, Sub-disciplines, ten main sub-disciplines fit with the general classification of majors of education. With regard to research topics and key concepts of papers, we drew upon the keyword system of CNKI as well as the keyword-analyzing software apCNKI and obtained a list of keywords. We discussed the list several times with the aim of being as comprehensive as possible, eliminating duplication and rarely occurring topics, and grouping and cross-referencing some key concepts, arriving at a list of 153 key concepts. We then tested category validity by consulting educational literature, documents as well as professorial colleagues. Table1 describes schematically the categories of content analysis which we investigated. The author developed a coding scheme and a coding book. The coding book was used by three graduates to code Category 1 - Sub-disciplines and Category 2 - Keywords.

\section{Table 1}

Categories of content analysis of the ER articles

\begin{tabular}{|c|c|}
\hline Categories & Content \\
\hline Sub-disciplines & $\begin{array}{l}10 \text { main sub-disciplines and } 44 \text { subdivisions of them were listed based on general } \\
\text { classification of education major, educational policies and literature review. Main } \\
\text { sub-disciplines include: educational principles, curriculum and teaching, history of } \\
\text { education, comparative education, special education, educational technology, educational } \\
\text { law, educational economy and management, teacher education and educational psychology. }\end{array}$ \\
\hline Research topics & 153 key concepts plus other were listed based on title, abstract and whole article. \\
\hline Research methods & $\begin{array}{l}2 \text { main methods were listed, including theoretical analysis and empirical research. The latter } \\
\text { was classified into, according to general educational research methods, observational study, } \\
\text { survey study, test method, experimental study, case study, interview, and other. }\end{array}$ \\
\hline Educational levels & $\begin{array}{l}5 \text { levels were listed that included preschool education, elementary education, secondary } \\
\text { education, basic education (including elementary and secondary education), college } \\
\text { education and no specified educational level. }\end{array}$ \\
\hline $\begin{array}{l}\text { Authors and their } \\
\text { backgrounds }\end{array}$ & These included number of authors and first author's background of country and region. \\
\hline References & These included number of references and sources of references based on languages. \\
\hline
\end{tabular}

Third, Cronbach's alpha was used to test multiple-coder reliability (Neuendorf, 2002). The author conducted a training lesson with the three graduate student coders, explaining categories and coding, testing of reliability 
Wang, $\mathrm{H}$.

and coding difficulties. The three graduates then undertook a pilot independently by coding the same 10 randomly-chosen articles published in a year for Category 1 and Category 2. The author tested the inter-coder reliability, which was 0.68 for Category 1 and 0.61 for Category 2. We then had some detailed discussion about general principles and specifics of coding and our interpretations of sub-disciplines and keywords, exploring our thinking and logic. The graduates then coded a further 10 articles independently and the inter-coder reliability was retested and found to be 0.91 for Category 1 and 0.95 for Category 2. Fourth, the graduate students coded a total of 3922 articles as indicated in Table 1 under the supervision of the author. Then the author conducted a numerical and statistical analysis with Excel and SPSS 20.0, and wrote the empirical paper.

\section{Results}

\subsection{Sub-disciplines}

Education, according to the directory of discipline classification designed by the Ministry of Education, was generally divided into 10 sub-disciplines as listed in Table 1. Educational principles $(f=1822,46.5)$ was the most frequently occurring main discipline followed by curriculum and teaching $(f=684,17.4 \%)$; and special education was the least $(f=8,0.2 \%)$ followed by educational technology $(f=48,1.2 \%)$, indicating that educational principles and curriculum and teaching are the main fields that educational research centers on. Special education, educational technology and educational psychology are somewhat ignored by the journal. In order to see if there was any change in the representation of sub-disciplines in papers published over the two decades, the author conducted a Chi-square test for each discipline to reflect the difference over years (see Table 2). The results showed that with the exclusion of curriculum and teaching, special education, educational technology and educational law, all other sub-disciplines show statistically significant patterns of difference according to Chi-square analysis. The number of papers of four sub-disciplines (educational principles, comparative education, educational economy and management, teacher education) increased significantly across the timeframe while the number of papers of two sub-disciplines (history of education, educational psychology) significantly decreased (see Figure 1).

Table 2

Sub-disciplines by decade

\begin{tabular}{|c|c|c|c|c|c|c|c|}
\hline & & 1994-1998 & $1999-2003$ & $2004-2008$ & 2009-2014 & Total & $X^{2}$ \\
\hline \multirow{4}{*}{$\begin{array}{l}\text { Educational } \\
\text { principles } \\
\text { Curriculum and } \\
\text { teaching }\end{array}$} & frequency & 344 & 393 & 462 & 623 & 1822 & \multirow{2}{*}{$97.55 * * *$} \\
\hline & percentage & $18.9 \%$ & $21.6 \%$ & $25.4 \%$ & $34.2 \%$ & $46.5 \%$ & \\
\hline & frequency & 144 & 187 & 176 & 177 & 684 & \multirow{2}{*}{6.12} \\
\hline & percentage & $21.1 \%$ & $27.3 \%$ & $25.7 \%$ & $25.9 \%$ & $17.4 \%$ & \\
\hline \multirow{2}{*}{ History of education } & frequency & 78 & 44 & 47 & 42 & 211 & \multirow{2}{*}{$16.36 *$} \\
\hline & percentage & $37.0 \%$ & $20.9 \%$ & $22.3 \%$ & $19.9 \%$ & $5.4 \%$ & \\
\hline \multirow{2}{*}{$\begin{array}{l}\text { Comparative } \\
\text { education }\end{array}$} & frequency & 50 & 36 & 41 & 94 & 221 & \multirow{2}{*}{$38.06 * * *$} \\
\hline & percentage & $22.6 \%$ & $16.3 \%$ & $18.6 \%$ & $42.5 \%$ & $5.6 \%$ & \\
\hline \multirow{2}{*}{ Special education } & frequency & 3 & 1 & 1 & 3 & 8 & \multirow{2}{*}{2.00} \\
\hline & percentage & $37.5 \%$ & $12.5 \%$ & $12.5 \%$ & $37.5 \%$ & $0.2 \%$ & \\
\hline \multirow{2}{*}{$\begin{array}{l}\text { Educational } \\
\text { technology }\end{array}$} & frequency & 11 & 12 & 11 & 14 & 48 & \multirow{2}{*}{0.50} \\
\hline & percentage & $22.9 \%$ & $25.0 \%$ & $22.9 \%$ & $29.2 \%$ & $1.2 \%$ & \\
\hline \multirow{2}{*}{ Educational law } & frequency & 24 & 32 & 27 & 30 & 113 & \multirow{2}{*}{1.30} \\
\hline & percentage & $21.2 \%$ & $28.3 \%$ & $23.9 \%$ & $26.5 \%$ & $2.9 \%$ & \\
\hline \multirow{2}{*}{$\begin{array}{l}\text { Educational economy } \\
\text { and management }\end{array}$} & frequency & 85 & 114 & 111 & 179 & 489 & \multirow{2}{*}{$39.29 * * *$} \\
\hline & percentage & $17.4 \%$ & $23.3 \%$ & $22.7 \%$ & $36.6 \%$ & $12.5 \%$ & \\
\hline \multirow{2}{*}{ Teacher education } & frequency & 17 & 40 & 65 & 111 & 233 & \multirow{2}{*}{$83.48 * * *$} \\
\hline & percentage & $7.3 \%$ & $17.2 \%$ & $27.9 \%$ & $47.6 \%$ & $5.9 \%$ & \\
\hline \multirow{3}{*}{$\begin{array}{l}\text { Educational } \\
\text { psychology }\end{array}$} & frequency & 30 & 35 & 10 & 18 & 93 & \multirow{3}{*}{$16.63 *$} \\
\hline & percentage & $32.3 \%$ & $37.6 \%$ & $10.8 \%$ & $19.4 \%$ & $2.4 \%$ & \\
\hline & frequency & 786 & 894 & 951 & 1291 & 3922 & \\
\hline
\end{tabular}

Note. $* * * p<0.001, * * p<0.01, * p<0.05$ 
Among all the sub-disciplines, teacher education needs to be paid special attention to. It was not the most frequently occurring sub-discipline, but the number of papers of it increased very sharply over 20 years from only 17 articles (1994-1998) to 111 articles (2009-2014). In contrast, the number of papers of history of education and educational psychology dropped markedly though they were not the smallest groups. It seemed that all sub-disciplines increased at the expense of educational psychology and history of education.

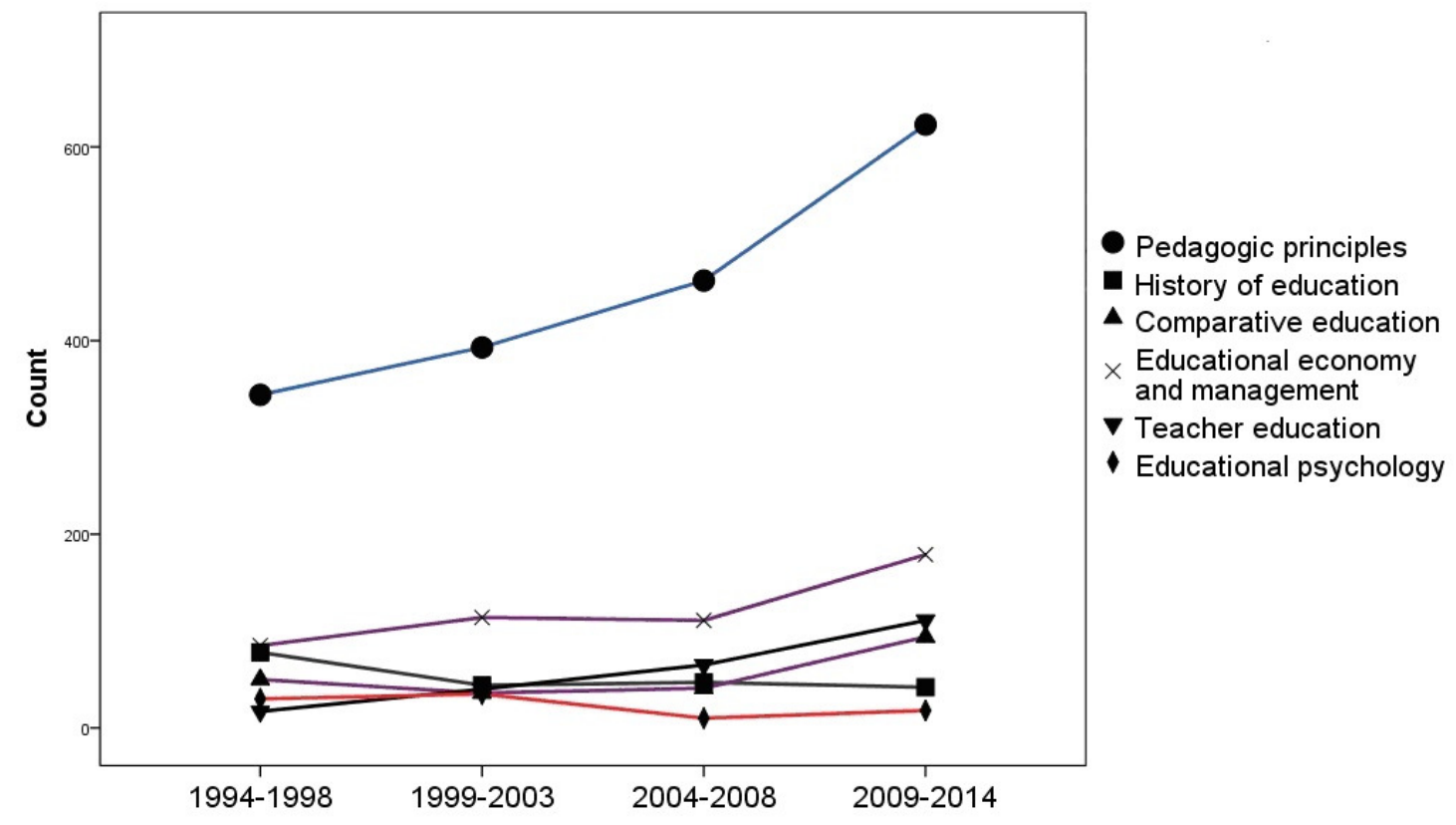

Figure 1. Trends of the six sub-disciplines over the past two decades

\subsection{Research topics}

Research topics in $E R$, which included key concepts, influential people as research topics and country/region focused on, were coded based on analyzing of title, keyword, abstract and whole article. Each article was coded using the list of 153 key concepts. A total of 128 of these key concepts occurred more than five times, 94 key concepts occurred 10 times, 56 key concepts 20 times, 18 key concepts 50 times and 7 key concepts 100 times. The 26 key concepts most frequently represented in the journal, each coded over one percent of the total and are shown in Table 3. Basic theory of education $(f=343,8.7 \%)$, teaching theory $(f=206,5.3 \%)$ and moral education $(f=160,4.1 \%)$ were the three key concepts occurred most frequently that were the traditionally focused research fields. Other frequent occurring were those key concepts of hot issues that were closely related with reality, including all-round education, vocational education, rural education, creative education, teacher development and so on.

With respect to trends of key concepts, among the 26 most frequently occurred, the number of 10 key concepts significantly increased over 20 years, including teacher education $\left(X^{2}=18.05, p<0.001\right)$, teacher development $\left(X^{2}=36.28, p<0.001\right)$, teacher specialization $\left(X^{2}=40.11, p<0.001\right)$, education reform $\left(X^{2}=29.50, p\right.$ $<0.001)$, vocational education $\left(X^{2}=24.61, p<0.001\right)$, school running $\left(X^{2}=26.36, p<0.001\right)$, function of education $\left(X^{2}=35.66, p<0.001\right)$, education management $\left(X^{2}=15.43, p<0.01\right)$, education development $\left(X^{2}=13.86\right.$, $p<0.01)$ and basic theory of education $\left(X^{2}=13.81, p<0.01\right)$. Likewise, key concepts of curriculum $\quad\left(X^{2}=19.33\right.$, $p<0.001)$ and creative education $\left(X^{2}=22.18, p<0.001\right)$ showed an increasing pattern but with a jump in the middle of the twenty years. On the contrary, the number of influential educators $\left(X^{2}=39.38, p<0.001\right)$ and all-around education $\left(X^{2}=9.63, p<0.05\right)$ declined significantly. On the whole, it appeared that key concepts related to teachers increased very sharply.

Further analysis showed that in 126 articles, influential people----altogether 58 including 17 foreigners - and 
Wang, $\mathrm{H}$.

their theories were research topics. The 15 influential people who occurred as research topics more than twice were ranked as follows: Deng Xiaoping $(f=23)$, Mao Zedong $(f=9)$, Tao Xingzhi $(f=7)$, Confucius $(f=6)$, Ye Shengtao $(f=6)$, Zhou Enlai $(f=6)$, Marx $(f=4)$, Dewey $(f=4)$, Huang Yanpei $(f=3)$, Liu Shaoqi $(f=3)$, Yang Xanjiang $(f=3)$, Cai Yuanpei $(f=2)$, Chen Heqin $(f=2)$, Li Bingde $(f=2)$, Tang Wenzhi $(f=2)$, Xu Teli $(f=2)$. Among all these, political figures (Deng Xiaoping, Mao Zedong, Zhou Enlai, Marx, Liu Shaoqi and Jiang Zeming) accounted for $36.5 \%$ of the total frequency. Dewey was the only non-Chinese to feature as a research topic for more than twice. Other non-Chinese scholars featured as research topics for only once were Socrates, Plato, Aristotle, Herbart, Kant, Lippmann, Rousseau, Rogers, Meumann, Lay, Noddings, Piaget, Jung, and Cyxomjnhcknn. A trend analysis showed articles on influential people declined over years.

Table 3

Frequency of the top 26 key concepts in ER

\begin{tabular}{|c|c|c|c|c|c|c|c|}
\hline Ranking & Key concept & $f$ & percentage & Ranking & Key concept & $f$ & percentage \\
\hline 1 & $\begin{array}{l}\text { Basic theory of } \\
\text { education }\end{array}$ & 343 & $8.7 \%$ & 14 & Education development & 58 & $1.5 \%$ \\
\hline 2 & Teaching theory & 206 & $5.3 \%$ & 15 & Learning & 53 & $1.4 \%$ \\
\hline 3 & Moral education & 160 & $4.1 \%$ & 16 & Teacher development & 53 & $1.4 \%$ \\
\hline 4 & $\begin{array}{l}\text { Education } \\
\text { management }\end{array}$ & 149 & $3.8 \%$ & 17 & All-around education & 51 & $1.3 \%$ \\
\hline 5 & Influential educators & 122 & $3.1 \%$ & 18 & Educational economy & 51 & $1.3 \%$ \\
\hline 6 & Curriculum & 120 & $3.1 \%$ & 19 & Rural education & 48 & $1.2 \%$ \\
\hline 7 & Teacher education & 107 & $2.7 \%$ & 20 & $\begin{array}{l}\text { Educational research } \\
\text { methods }\end{array}$ & 46 & $1.2 \%$ \\
\hline 8 & $\begin{array}{l}\text { Vocational } \\
\text { education }\end{array}$ & 92 & $2.3 \%$ & 21 & Private education & 45 & $1.1 \%$ \\
\hline 9 & Education reform & 80 & $2.0 \%$ & 22 & Creative education & 44 & $1.1 \%$ \\
\hline 10 & $\begin{array}{l}\text { Educational law and } \\
\text { policy }\end{array}$ & 79 & $2.0 \%$ & 23 & School running & 44 & $1.1 \%$ \\
\hline 11 & Pedagogy & 77 & $2.0 \%$ & 24 & Educational research & 41 & $1.0 \%$ \\
\hline 12 & $\begin{array}{l}\text { Function of } \\
\text { education }\end{array}$ & 73 & $1.9 \%$ & 25 & $\begin{array}{l}\text { Education of information } \\
\text { technology }\end{array}$ & 41 & $1.0 \%$ \\
\hline 13 & $\begin{array}{l}\text { Cognitive } \\
\text { psychology }\end{array}$ & 71 & $1.8 \%$ & 26 & Teacher specialization & 38 & $1.0 \%$ \\
\hline
\end{tabular}

194 articles focused on specific country or region in their title. A total of 19 countries or regions were explicitly mentioned as research topics. The top 10 countries or regions which were all mentioned more than three times in titles were ranked as follows: United Sates of America $(f=43)$, Japan $(f=21)$, United Kingdom $(f=10)$, Germany $(f=4)$, Russia $(f=4)$, South Korea $(f=4)$, Hong Kong $(f=4)$, France $(f=3)$, Taiwan $(f=3)$, India $(f=3)$. In addition, instead of mentioning specific country or region in their title, 63 articles focused on broader international regions like international $(f=27)$, western $(f=14)$, foreign $(f=9)$, Europe $(f=6)$, Sino-foreign $(f=4)$ and developing countries $(f=3)$. Generally, research on education of different countries and regions increased over years, from 40 articles (1994-1998), to 37 (1999-2003), to 46 (2004-2008), to 71 (2009-2014). In particular, the frequency of education in USA as a research topic increased overall, from 6 (1994-1998), to 8 (1999-2003), to 12 (2004-2008), to 17 (2009-2014).

\subsection{Research methods and methodologies}

As $E R$ is a journal that traditionally focused on theoretical and philosophical analysis and macro issues, research methods were classified into theoretical and empirical research and each of the 3922 papers was coded for only one method that dominated it. The findings showed that the overwhelming majority of papers $(f=3540$, 90.3\%) published in $E R$ used the method of theoretical research. Other methods were ranked as follows: survey $(f=201,5.1 \%)$, experimentation $(f=75,1.9 \%)$, interview $(f=36,0.9 \%)$, test $(f=30,0.8 \%)$, case study $(f=26$, $0.7 \%)$, observation $(f=7,0.2 \%)$ and others $(f=7,0.2 \%)$. 
A view of educational research in China: A content analysis of the journal of Educational Research

Papers that used theoretical research significantly increased over time $\left(X^{2}=120.68, p=<0.001\right)$, from 696 (1994-1998), to 835 (1999-2003), to 864 (2004-2008), to 1145 (2009-2014). Survey papers significantly increased too $\left(X^{2}=80.86, p<0.001\right)$, from 25 (1994-1998), to 19 (1999-2003), to 56 (2004-2008), to 101 (2009-2014); so did test $\left(X^{2}=26.59, p<0.001\right)$ and case study $\left(X^{2}=9.400, p<0.05\right)$, from 4(1994-1998), to 2 (1999-2003), to 5 (2004-2008) to 19 (2009-2014), and from 3(1994-1998), to 3 (1999-2003), to 11 (2004-2008), to 9 (2009-2014) , respectively. Papers of observation increased as well but not significantly, from 0 (1994-1998), to 0 (1999-2003), to 1 (2004-2008), to 6 (2009-2014). Papers of experimentation significantly decreased over 20 years $\left(X^{2}=57.02, p<0.001\right)$, from 44 (1994-1998), to 24 (1999-2003), to 4 (2004-2008), to 3 (2009-2014). Interview papers dropped too but not significantly, from 12 (1994-1998), to 9 (1999-2003), to 8 (2004-2008), to 7 (2009-2014).

Further analysis showed that most articles of survey were based on questionnaires and almost all experimental studies used quasi-experimental research. As the number of experimentation papers decreased markedly, especially in the past decade, empirical research has more often focused on surveys, interviews and case study.

\subsection{Educational levels}

Educational levels to which papers published in $E R$ referred were divided into six levels and no specified educational level. More than half of papers $(f=2582,65.8 \%)$ did not refer to any specific educational level. These were generally theoretical papers. Articles related to a specific educational level were ranked as follows: college education $(f=797,20.3 \%)$, basic education $(f=285,7.3 \%)$, secondary education $(f=150,3.8 \%)$, elementary education $(f=78,2 \%)$ and preschool education $(f=30,0.8 \%)$. The number of papers without no specified educational level significantly increased over 20 years $\left(X^{2}=280.57, p<0.001\right)$, from 552 (1994-1998), to 655 (1999-2003), to 582 (2004-2008), to 793 (2009-2014); so did papers related to college education and basic education, from 102 (1994-1998), to 142 (1999-2003), to 239 (2004-2008), to 314 (2009-2014), and from 52 (1994-1998), to 44 (1999-2003), to 92 (2004-2008), to 97 (2009-2014) respectively. Papers about preschool education significantly increased as well but the total frequency was relatively small. Papers relating to secondary education slightly increased and papers relating to elementary school decreased but there was no significant change over time.

With respect to research methods, most papers $(f=2490,70.4 \%)$ using theoretical approach didn't refer to any specified educational level. Papers related to theoretical research that referred to a specified educational level mainly focused on college education $(f=729,20.6 \%)$. Experimentation was mostly used at basic education level $(f=76,72.7 \%)$, so was questionnaire survey $(f=98,49.2 \%)$. Interview study, on the other hand, was largely used for interviewing administrative officials $(f=19,54.3 \%)$. The results indicated that $E R$ emphasized and preferred philosophically theoretical articles that aimed at no specified educational level or centered on college education.

\subsection{Authors and their backgrounds}

Most of the 3922 papers published in $E R$ over 20 years were single-authored $(f=2602,66.3 \%) .23 .4 \%$ ( $f=919)$ of papers had two authors. Fewer than $10 \%$ of papers had multiple authors: $4.6 \%(f=179)$ had three authors, 1.4\% $(f=53)$ had four authors, $0.9 \%(f=36)$ had five authors, $0.5 \%(f=19)$ had six authors, $0.2 \%(f=6)$ had seven authors and only one paper had eight authors. The rest of papers $(f=107,2.7 \%)$ didn't have individual authors but had research team as an author.

With regard to research methods, theoretical research accounted for most of papers with one author and more than one author. Percentage of papers based on theoretical analysis with one to seven authors was ranked as follow: one author $(f=2468,94.9 \%)$, two authors $(f=798,86.8 \%)$, five authors $(f=29,80.6 \%)$, three authors $(f=130,72.6 \%)$, four authors $(f=36,67.9 \%)$, seven authors $(f=4,66.7 \%)$ and six authors $(f=10,52.6 \%)$. The only 
Wang, $\mathrm{H}$.

eight-author paper was also based on theoretical research. Further analysis on papers with more than three authors $(f=115)$ showed only $30.4 \%$ ( $f=35)$ of papers were based on empirical research, suggesting that papers with multiple authors did not necessarily have to be based on empirical methods.

Analysis revealed that the first authors' affiliated institutions were situated in a total of 13 countries and regions. Most of the 3922 papers came from mainland China $(f=3854,98.3 \%) .44$ papers $(1.1 \%)$ came from other 11 countries. Of the 44 papers, about half $(f=19,43.2 \%)$ came from USA. Other 10 countries in which the first authors' affiliated institutions were located were as follows: UK $(f=6)$, Canada $(f=5)$, Japan $(f=5)$, India $(f=2)$, Russia $(f=2)$, Australia $(f=1)$, Finland $(f=1)$, Greece $(f=1)$, Spain $(f=1)$ and New Zealand $(f=1)$. In addition, there were 11 papers from Hong Kong and 13 papers were co-authored by Chinese-foreign scholars. Papers by authors whose institutions were outside mainland China were either written in Chinese by themselves if their native language was Chinese or translated into Chinese if not, indicating that not a single person whose mother tongue was not Chinese were able to write an article in Chinese and published it in $E R$.

The number of countries and regions with the exception of mainland China in which the institutions of the first authors of published papers were located increased in the past twenty years, from 7 (1994-1998), to 12 (1999-2003), to 19 (2004-2008), to 17 (2009-2014). In particular, the number of papers whose first authors were affiliated to institutions in the USA has increased in the past two decades, reflecting $E R$ 's tendency for introducing western education, especially education in the USA to China.

\subsection{References and citations}

An analysis was undertaken of the number of references of each paper. References were also analyzed according to three categories: Chinese references, non-Chinese references and translated-into-Chinese references. Trends by decade were considered as well.

References listed in the 3922 papers had a mean score of 7.68 ( $S D=5.508)$. Among the three kinds of references, the number of Chinese references was bigger than that of non-Chinese references and that of translated-into-Chinese references (see Table 4). Overwhelming majority of non-Chinese references was in English and most of translated-into-Chinese references were based on English as well. In addition, among 3922 papers, there were $559(14.3 \%)$ papers without any references, 779 (19.9\%) papers without any Chinese references, $2130(54.3 \%)$ papers without any non-Chinese references and $2745(70 \%)$ papers without any translated-into-Chinese references.

\section{Table 4}

Descriptive statistics for references listed in ER

\begin{tabular}{lccccc}
\hline & $\mathrm{N}$ & Minimum & Maximum & Mean & Std. Deviation \\
\hline Chinese references & 3922 & 0 & 105.00 & 4.78 & 5.508 \\
Non-Chinese references & 3922 & 0 & 30.00 & 1.45 & 2.478 \\
Translated-into-Chinese references & 3922 & 0 & 68.00 & 1.46 & 3.984 \\
\hline
\end{tabular}

With respect to trends over 20 years, mean scores of three kinds of references increased in the past decade. Mean score of Chinese references increased from 3.4 (1994-1998) to 5.6 (2009-2014); mean score of non-Chinese references increased from 1.0 (1994-1998) to 1.7 (2009-2014); mean score of translated-into-Chinese references increased from 0.7 (1994-1998) to 2.0 (2009-2014) and mean score of the total references increased from 5.1 (1994-1998) to 9.3 (2009-2014). Papers without any references decreased from 293(1994-1998), to 137 (1999-2003), to 75 (2004-2008), to 54 (2009-2014). The findings suggested that as time went on, authors whose papers were published in $E R$ were more likely to add more references in their papers and Chinese references have always been the main source of citations listed in $E R$. 


\section{Discussion}

It is not surprising to find that nearly half of papers published in $E R$ over 20 years belonged to the field of educational principles and papers of educational principles have increased dramatically over years. Historically, this sub-discipline has been educational scholars' favorite research area. Feng (2007) argued that this was because educational principles were the basics of educational research that dominated the field. But a further analysis on the relation between papers of educational principles and methods used in them reveals that papers of educational principles that used theoretical research accounted for over half of all papers that used the same method, suggesting that educational principles is a field that may be suitable for using the method of theoretical research, which is, most education scholars are good at. Besides, educational principles have an ambiguous and broad definition that possibly allows more scholars of different backgrounds to join in the group of theoretical discussion (Fang, 2001).

Another interesting finding is that papers related to higher education increased markedly and accounted for most of papers with specific educational level. As ER is not a journal specializing in higher education, this trend is very noticeable. Considering the vast majority of educational researchers either work in colleges or in research institutions affiliated to colleges, it seems reasonable to expect the focus of higher education. However, education in China is more political than scientific. Scholars with position of government officials, for example, presidents or party secretaries of colleges, have a lot of power in manipulating academic research (Wu, 2009). These scholars may be interested in higher education since their work has to do with higher education management and policy interpretation. There's no denying, though, that doing articles related to their working experience is convenient and easily available, especially when it is based on theoretical approaches. Recently, demands for de-administration----calling for eliminating negative effects of bureaucracy on education----have become more and more strident (Xiong \& Zheng, 2011). But the change of effects of administrative powers on education doesn't seem likely to occur in the near future, and the higher-education-dominated orientation will remain for a relatively long period of time.

It is also noteworthy that in terms of sub-disciplines, only papers about history of education and educational psychology decreased. Reduction of research on history of education is partly due to a small number of scholars involved in this area. In addition, research on history requires good language ability----either good Chinese, especially ancient Chinese prose, or good foreign language----which may prevent scholars from pursuing this field. The reason that the numbers of papers of educational psychology were small and decreased was that, one the one hand, with more and more departments of psychology going independent from schools of education where they used to be affiliated to, scholars of education and scholars of psychology were unwilling to communicate with each other because of their different backgrounds and research orientations (Luo, 2008); on the other hand, scholars of education prefer huge topics based on theoretical and philosophical inquiry whereas scholars of psychology attach importance to specific topics and empirical methods, hence papers of psychology may be more likely to be rejected by $E R$.

A problem in regard of research methods is that papers published in $E R$ placed so much weight on theoretical research. The vast majority of these papers used theoretical research and was opinionated, less objective without empirical evidence. Some even didn't have any references. No doubt Chinese scholars' preference of theoretical research has much to do with their research orientation, but it also has something to do with their backgrounds and the research paradigm they have been familiar with and accustomed to. Chinese intellectuals have long been influenced by the tradition of talking emptiness, a Taoism way of explaining the world focusing on abstract and ambiguous theories. This is especially true for scholars of arts and humanities because they are more likely to inherit the tradition of neglecting data and evidence than those of sciences. Such inclination is characterized by paltry number of empirical papers. Some researchers realized the disadvantage of putting too much emphasis on theoretical research and called for a comprehensive use of qualitative and quantitative research (Zhu, 2005; Yao \& Wang, 2013). And indeed, quantitative research such as questionnaire survey increased and became the most frequently-used empirical method. But the problem is, the highlight of 
using survey as major empirical method may reveal a passive response to the demand of carrying out research based on data and evidence. Comparing with other research methods, survey is convenient, economical and seemingly easy to design, thus becoming the only alternative to most educational researchers. Moreover, loosely using survey caused inappropriate sampling, lack of reliability and validity, overly relying on descriptive statistics and other problems that undermined the quality of research (Yao \& Wang, 2013).

There were a number of papers whose key concepts were related to practice. These were among the most frequently occurring such as educational reform, vocational education, school running, rural education, private education and creative education. Moreover, researchers were also encouraged to select those topics that the government was concerned about. Research topics such as Marxism education, all-round education, rural education, anti-illiteracy education, left-behind children, burden reduction, dropouts and school choice were also among top occurring key concepts that were related to government policy-making. Further analysis showed contents of these papers were mostly about discussion of definition or significance of the concepts, which reveals that educational research mainly dealt with construction of theory based on essentialism but failed to pay enough attention to practice (Wang \& Wang, 2007). Liu and Wang (2013) argued that educational research played an active role in guiding educational policies and practice. But in many cases it just lagged behind them. For example, it was not until 1999, the year in which the Enrollment Expansion of Colleges was implemented, that research on teaching evaluation, educational inputs and outputs, quantity and quality of new teachers started to increase, suggesting the growing concern for such issues were closely related to that policy. There were other data to show educational research was subject to government policy. For example, over half of papers on all-round education $(f=30,58.8 \%)$ were published after the Chinese Party Central Committee and the State Council issued the document of Deepening Educational Reform, Promoting Quality-oriented Education in 1999. Likewise, most papers $(f=51,63.8 \%)$ about educational reform appeared after The Program of National Curriculum Reform for Basic Education was issued in 2001. Much research on teaching reform, function of education, school running, and educational development also came out after the Program of Educational Planning was carried out in 2010. A more typical example of such research is teacher education. Before the National Teachers' Training Program for Basic Education was implemented in 2010, there were only 7.2 papers about teacher education published in $E R$ per year, but the number increased to 20 after that, indicating that researchers' interest was probably inspired and driven by that policy.

In addition to research directly under the influence of government policy, the journal also published a certain number of papers that were tied up with political reality. Moral education, for example, is a major part of educational research. Of all key concepts, moral education was the third most frequently occurring concept, only second to basic theory of education and teaching theory. Another political aspect of educational research is that political figures who occurred as research topics dominated research with distinguished people as research topics. Mao Zedong, Deng Xiaoping, Zhou Enlai, and Liu Shaoqi were all top party and state leaders. They were considered great thinkers and educators but obviously the journal and researchers' interest in writing them was largely due to their political influence. Further analysis showed that papers with political figures as research topics mostly appeared during the period from 1994 to 1999 and the trend decreased over time. Until now, no research about present top leader Xi Jinping and his predecessor, Hu Jintao has been published in the journal. A study on references in $E R$ also showed that works of Marxism were the most frequently-quoted references but the citations of it have sharply decreased (Cheng, Zhang, \& Du, 2012). This may suggest that the journal and researchers are altering the emphasis of directly connecting educational research to political ideology.

To increase internationalization and extend its influence, $E R$ introduced some articles by some well-known scholars in some well-known universities and institutions outside China. It also published some articles introducing education in other countries and regions. Besides, $E R$ attempts to standardize papers published in it by encouraging authors to format their manuscripts as well as add more references. However, there are still papers without any references published in recent issues. Some researchers noted that educational research in China faced a problem of contradiction that prevented it from being internationalization. On the one hand, lots of Chinese scholars think highly of western educational theories----mainly English----and many of them had 
A view of educational research in China: A content analysis of the journal of Educational Research

experience of studying abroad; on the other hand, they seemingly quoted few original non-Chinese references in their papers (Zhang, Chen, Zhu, \& Luo, 2009). According to a report conducted by International Academic Literature Evaluation Research Center and Tsinghua University Library, there were 34 journals on its list of the Highest International Impact Academic Journals (Humanities and Social Sciences) of China, including two psychological journals and three physical education journals but not a single education journal (China Academic Journals Electronic Publishing House, 2014). This suggests that there exists a gap of internationalization between education journals and other humanities and social sciences journals. Du's study (2003) showed that since 1960s, emphases of world's educational research had transferred to educational policy, education and its relation to government, family and community and concern about students. Chinese scholars don't seem to respond to the change. Instead, they seem to take it for granted that solving practical problems or educational policy-making don't need to be based on scientific research (Yuan, 1999). As a result, they may agree with and be satisfied with the conception that the role of educational research is to follow and interpret government policy. This would hinder Chinese researchers of education, in a manner, from communicating with their international counterpart and make it even harder and slower to internationalize educational research in China.

\subsection{Implications}

Based on the quantitative analysis and a qualitative chronological processing of the papers published on $E R$, this study may raise some issues for future goals and practices for $E R$, and even for educational research in China as a whole. First, interdisciplinary approaches and empirical research need to be emphasized. Education scholars and researchers outside education need to be encouraged to conduct their research on the basis of multi-methods to make reasoned arguments, not just theoretical research. Secondly, educational research should deal with balancing theory, educational policy and keeping a relationship with practice. Educational research needs to work as a follower of educational policy as well as an instructor. Finally, to introduce world's education and extend influence of its own, educational research in China need to pay close attention to reality both in China and abroad without neglecting international academic orientations.

\subsection{Limitations of the Study}

It is generally acknowledged that $E R$ enjoys a high reputation and has made a leading contribution to the field of education research. However, this study is only based on content analysis on papers published in $E R$, not on papers published in other journals or books. Thus it is difficult to generalize education in China as a whole.

\section{Conclusions}

Over the past 20 years $E R$ has reflected the change of research on education in China. Taken altogether, the trend of attaching too much importance to theoretical research hasn't changed much and papers based on empirical research were only a small portion of all the papers published in ER though some kind of empirical papers have increased slightly. In addition, educational research in China had a close connection with indigenization and politicization, though there was concern about internationalization and popularization of educational practice. Since 1990s, occasionally there has been call for research on practical issues and going with the trend of world's educational research, but apparently Chinese educators and education researchers haven't well prepared for that.

Acknowledgements: I should like to thank three coders for their support in this study. They are: 贺文凯 (Wenkai He), 祝叶( Ye Zhu) and 张伟 (Wei Zhang). 


\section{References}

Cheng, L., Zhang, Y., \& Du, M. F. (2012). dāng dài zhōng guó jiāo yù yán jiū zhōng mă kè sī zhǔ yì de yǐng xiăng lì — _ jī yú《jiāo yù yán jiū》(1979-2008) cān kăo wén xiàn de fèn xī [The Influence of Marxism on educational research in Contemporary China: Based on the analysis of references in the journal of Educational Research (1979-2008)]. jī chǔ jiāo yù [Journal of Schooling Studies], 9 (5), 5-10.

China Academic Journals Electronic Publishing House. (2014). 2012 The Highest International Impact Academic Journals (Humanities and Social Sciences). Retrieved May 10, 2015, from http://hii.cnki.net/cajz/topmag.aspx?page=1\&tabid=2\#tab/2014-11-20

Du, X. L. (2003). jiāo yù yán jiū zhòng xīn de zhuăn yí __yǐ 《hā fó jiāo yù píng lùn 》wéi lì [Emphases transfer of educational research supported by the study on Harvard Educational Review]. Unpublished doctoral dissertation, East China Normal University, China.

Fang, Z. H. (2001). guān yú “jiāo yù yuán lǐ ”de yī zhǒng xīn quán shì [A new annotation about educational principles]. jiāo yù yán jiū yǔ shí yàn [Educational Research and Experiment], (1), 1-7.

Feng, J. (2007). guān yú "jiāo yù yuán lǐ "de xué kē chēng wèi yǔ nèi róng xiàn zhuàng de yán jiū [Study on discipline designation and content status of principles of education]. jiāo yù lǐ lùn yǔ shí jiàn [Theory and Practice of Education], 27 (4), 1-5.

Gan, H. (2013). wǒ guó gāo děng jiāo yù yán jiū guó jì huà de kùn jìng yǔ xuăn zé [The study on China’s higher education in world perspective]. zhōng guó gāo jiāo yán jīu [China Higher Education Research], (5), $9-12$.

Institute of Scientific and Technical Information of China. (2011). zhōng guó qū kān y̌̀n zhèng bào gào [Chinese Journal Citation Reports]. Beijing: kē xué jì shù wén xiàn chū băn shè [Scientific and Technical Documentation Press].

Liu, H. M., \& Wang, S. (2013). zhòng dà chéng jiù :jiāo yù jī běn lǐ lùn de chuàng xīn fā zhăn [Great achievements: Innovation and development of basic education theories]. jiāo yù yán jiū [Educational Research], (2), 33-36.

Luo, D. H. (2008). jiāo yù xué yǔ xīn lǐ xué jī chǔ guān xì de tàn xún [Exploration of the fundamental relation between educology and psychology]. Unpublished doctoral dissertation, East China Normal University, China.

Neuendorf, K. A. (2002). The content analysis guidebook. Thousand Oaks, CA: Sage.

Pan, M. Y. (2006). zhōng guó gāo děng jiāo yù yán jiū de lì shǐ yǔ wèi lái [Higher education research in China: Past and prospect]. zhōng guó dì zhì dà xué xué bào (shè huì kē xué băn ) [Journal of China University of Geosciences (Social Sciences Edition)], 6(5), 2-6.

Tian, Z. P., \& Shang, L. H. (2003). zhōng guó jiāo yù qī kān de xiàn dài huà tè zhēng [The modernization features of Chinese educational journals]. gāo děng jiāo yù yán jiū [Journal of Higher Education], 24(1), 83-88.

Wang, Z. J., \& Wang, Y. C. (2007). jiāo yù yán jiū de "zhǔ yì "lùn shù yǔ zhī shí xué fāng shì de fèn yě [On division of doctrine expound and the way of knowledgeology in education research]. xī běi shī dà xué bào (shè huì kē xué băn ) [ Journal of Northwest Normal University (Social Sciences)], 44(4), 44-47.

Wu, W. (2009). wǒ guó gāo xiào háng zhèng quán lì fàn huà wèn tí tàn xī [On generalization of administrative power in Chinese colleges and universities]. sū zhōu dà xué xué bào (zhé xué shè huì kē xué băn ) [Journal of Suzhou University (Philosophy \& Social Science)], (1), 119-121.

Xiong, W. Z., \& Zheng, Y. (2011). gāo děng jiāo yù qù háng zhèng huà de jī běn wèn tí jí qí duì cè ——yǔ fă lü guī zhì wéi hé xīn shì jiăo [The basic issues and countermeasures on the de-administration of higher education]. běi jīng háng zhèng xué yuàn xué bào [Journal of Beijing Administrative College], (3), $86-92$.

Yao, J. H., \& Wang, X. X. (2013). jìn shí nián lái wǒ guó jiāo yù yán jiū fāng fă de fèn xī yŭ făn sī [Analysis and reflection on educational research method in recent ten years in China]. jiāo yù yán jiū [Educational Research], (3), 20-24.

Yuan, Z. G. (1999). jiāo yù zhòng xīn de zhuăn yí [Emphases transfer of educational research]. jiāo yù yán jiū 
A view of educational research in China: A content analysis of the journal of Educational Research

[Educational Research], (7), 11-14.

Zhang, B. X., Chen, Y., Zhu, H., \& Luo, X. L. (2009). jìn sān shí nián wǒ guó jiāo yù zhī shí lái yuán de biàn qiān — jī yú 《jiāo yù yán jiūu 》zá zhì lùn wén y̌̌n wén de yán jiū [Transitions of the source of Chinese educational knowledge in the recent 30 years: Based on the research on the quoted papers in the magazine of "Educational Research"]. jiāo yù yán jiü [Educational Research], (4), 17-25.

Zhang, Y. Q. (2010). zhōng guó jiāo yù yán jiū de fàn shì hé fàn shì zhuăn huàn —_jiān lùn jiāo yù yán jiū de wén huà xué fàn shì [Paradigm of educational research and paradigm transformation in China]. jiāo yù yán jīü [Educational Research], (10), 3-10.

Zhu, Z. Y. (2005). jiāo yù yán jiū fāng fă lùn fàn shì yŭ fāng fă de făn sī [Reflection on paradigms and methodologies of educational research]. jiāo yù yán jiū yǔ shí yàn [Educational Research and Experiment], (1), 7-12. 
Wang, $\mathrm{H}$. 